\title{
Comparison Of Pupils' Completion Rate Before And During 2006/2007 School Feeding Programme In Selected Public Primary Schools In Rivers State, Nigeria
}

\author{
Dr. Nnamdi Anero \\ Department Of Early Childhood And Primary Education, \\ Faculty Of Education, Ignatius Ajuru University Of Education, \\ Rumuolumeni, P. M. B. 5047. Port Harcourt, Rivers State.
}

\begin{abstract}
The study titled 'Comparison of pupils' completion rate before and during 2006/2007 school feeding programme in selected public primary schools in Rivers State, Nigeria was carried out to determine the impact of the feeding programme on the pupils' completion rate. The study compared the completion rate of pupils before and during the feeding programme and also investigated the completion rate on the bases of boys and girls as well as urban and rural pupils. Out of 868 schools in Rivers State, 44 schools were randomly selected for the study. The Head teachers of the selected schools were requested to supply relevant records of the pupils' enrolment, dropout, return and completion rates using the admission and attendance registers as well as the result schedules. The figures generated from the records were analyzed using simple percentages. Based on the analysis, the study established that completion rate during the feeding programme was higher than when there was no feeding among pupils in Rivers State. The study further established that there was no significant difference between the completion rates of the urban and rural pupils during or before the feeding programme and also established that more males completed primary education than females during the feeding programme in Rivers State. It therefore recommended that the government should re-introduce the feeding progamme and also carry out enlightenment campaign among the rural dwellers to enable them fully utilize the opportunity as well as seek for participation of philanthropists in funding the programme in all the nooks and crannies of the state so that all and sundry shall benefit.
\end{abstract}

\section{INTRODUCTION}

Government of nations have demonstrated willingness for all her citizens to acquire primary education. This gesture is observed through their policy declarations. Indeed, the government of most nations go beyond policy formulation by executing specific schemes to actualize the goals of some policies. In Nigeria, the efforts of government to offer primary education to all are felt by several programmes. List of such programmes remains incomplete without the inclusion of the attempts made by various state governments at different times to feed pupils while in school. Formulating and implementing programmes assumed to serve as a catalyst for adequate enrolment, transition and completion of pupils without ascertaining the extent such programmes faired in attaining set goals may not be useful to educational planners and managers. This thinking super impose the need to find out the impact of the 2005/2006 and 2006/2007 academic sessions feeding programme in Rivers State with particular attention to pupils' primary six completion rate.

Naturally, one may ask why demonstrate curiosity to find out the extent the 2005/2006 and 2006/2007 abandoned pupils' feeding programme impact on completion rate and ignore other elements of schooling such as enrolment and transition rates. Providing answer to this, Gaduya 
(2018) explained that enrolment is mere introduction of the child to school; transition tells the progress the child makes from one class to another while completion is the demonstration of the child's capacity to complete a full course of primary school education. By the descriptions, the flesh of the matter lies on completion. Since completion is the focus of all programmes and policies, there is the need to find out if there was a boast or the situation never changed by comparing the completion rate of pupils before and after the feeding programme.

The abandoned school feeding programme has left the hearts of most educators and school managers to ponder by contemplating on the following:

1. who knows if the completion rates of pupils' primary education in Rivers State before and during the feeding programme were the same?;

2. if the completion rate, improved in the favour of the feeding period, why was the feeding abandoned?; and

3. if the completion rate, improved in the favour of the feeding period, what can be done to resource-state it?;

Beyond the afore-stated considerations as stated in the immediate last three sentences, the Researcher is further informed to embark on this study because several findings have related school completion rate, learning outcomes, delay in reaching developmental milestones refusal to attend school, and difficulty in fighting infection among children to child's feeding (Breakly, 1997, Otive, 2006 and Betha, 2007).

In view of the need to provide answers to the questions and the submissions made by Breakly, Otive and Betha, it is apparent that feeding has significant effects on the child in many ways. In this study however, attention is given to how it affects the child's rate of completing primary education by comparing the pupils' rate of completion before and during the feeding programme. In doing so, certain question may naturally arise. Some of such questions are:

1. at what rate did the pupils complete primary education during and before the feeding programme in the state?; and

2. did factors such as school location and sex of pupils affect the completion rate during and before the feeding programme?

The provision of answers to the questions remains the nucleus of this study.

\section{PURPOSE OF THE STUDY}

This study was carried out to find out:

1. the rate at which pupils complete primary education before and during the feeding programme in Rivers State;

2. the rate at which pupils in urban and rural schools complete primary education before and during the feeding programme; and

3. the rate at which male and female pupils complete primary education before and during the feeding programme.

\section{RESEARCH QUESTIONS}

The following research questions were posed.

1. At what rate did pupils in Rivers State complete primary education before and during the feeding programe?

2. At what rate did urban and rural pupils complete primary education before and during the feeding programme?

3. At what rate did male and female pupils complete primary education before and during the feeding programme? 


\section{DEFINITION OF TERMS}

For the purpose of this study, the following terms shall be understood as defined.

1. Completion rate: In this study, it is used to refer to pupils who completed a course of primary education without dropping out of school.

2. School feeding programme: This is a term used in this study to refer to free provision of food to pupils while they are in school.

\section{METHODOLOGY}

868 Head teachers in the 868 public primary schools constitute the population of the study. The Head teachers were considered the most appropriate subjects for the study because they are the custodian of the needed information for this study. The school records needed for the study would be extracted from school admission/attendance registers and examination result schedules. To select 5\% of the 868 schools, proportional stratified sampling technique was employed to group the teachers into 2 strata. The stratification was done on the basis of school location (rural and urban). Urban schools were 260 while rural schools were 608 (Rivers State Universal Education Board, 2012). To select 5\% of the schools (Head teachers) for the study, the Researcher wrote the names of each of the rural and urban schools on slips of papers and put them into separate bags tagged urban and rural schools. After which the Researcher adopted balloting-with-replacement to select 31 rural and 13 urban schools (Head teachers) respectively. In all $44 \mathrm{Head}$ teachers were interviewed and relevant records obtained. The 44 Head teachers or schools represented $5.07 \%$ of the Head teachers or schools in Rivers State pubic primary schools.

\section{Instrumentation}

The instrument for the study was a table designed by the Researcher for the Head teachers to fill. The table is as shown in table one.

Table one: Records of different academic sessions showing enrolment, drop out, completion and return rates of pupils in Rivers State public primary schools.

Instruction: Kindly supply the necessary information as required in this table

\begin{tabular}{|c|c|c|c|c|c|c|c|c|c|c|c|c|}
\hline \multirow[t]{2}{*}{$\begin{array}{l}\text { School Location } \\
\text { Urban:....... } \\
\text { Rural:........ }\end{array}$} & \multicolumn{3}{|c|}{$\begin{array}{l}1998 / 1999 \text { to } \\
2003 / 2004 \\
\text { academic session }\end{array}$} & \multicolumn{3}{|c|}{$\begin{array}{l}1999 / 2000 \text { to } \\
2004 / 2005 \\
\text { academic session }\end{array}$} & \multicolumn{3}{|c|}{$\begin{array}{l}2000 / 2001 \text { to } \\
2005 / 2006 \\
\text { academic session }\end{array}$} & \multicolumn{3}{|c|}{$\begin{array}{l}2001 / 2002 \text { to } \\
2006 / 2007 \\
\text { academic session }\end{array}$} \\
\hline & Boys & Girls & Total & Boys & Girls & Total & Boys & Girls & Total & Boys & Girls & Total \\
\hline No. of enrolment & & & & & & & & & & & & \\
\hline No. of dropouts & & & & & & & & & & & & \\
\hline $\begin{array}{l}\text { No. of } \\
\text { completion }\end{array}$ & & & & & & & & & & & & \\
\hline $\begin{array}{l}\text { No. of those that } \\
\text { returned back to } \\
\text { school }\end{array}$ & & & & & & & & & & & & \\
\hline
\end{tabular}

\section{Administration of Instrument}

To ensure effective administration and retrieved of the instrument, the Researcher had one-onone interaction with the 44 respondents. In course of the interaction, he introduced himself, sought for permission, made necessary clarifications in filling the table, ascertained when to come back to retrieve the instrument. Following the successful administration and retrieval of the instrument, the needed information for the study was generated.

\section{DATA ANALYSIS}

The data generated was analyzed using simple percentages. 
Research question one: At what rate did pupils in Rivers State complete primary education before and during the feeding programme?

Table two: Percentage analysis of pupils' completion rate before and during the feeding programme in Rivers State.

\begin{tabular}{|c|c|c|c|c|}
\hline & \multicolumn{2}{|c|}{ Before the feeding programme } & \multicolumn{2}{|c|}{ During the feeding programme } \\
\hline & $\begin{array}{l}1998 / 1999 \text { To } \\
2003 / 2004 \\
\text { academic session }\end{array}$ & $\begin{array}{l}1999 / 2000 \text { to } \\
2004 / 2005 \\
\text { academic session }\end{array}$ & $\begin{array}{l}2000 / 2001 \text { to } \\
2005 / 2006 \\
\text { academic session }\end{array}$ & $\begin{array}{l}2001 / 2002 \text { to } \\
2006 / 2007 \\
\text { academic session }\end{array}$ \\
\hline Enrolment & 3040 & 3227 & 3527 & 3672 \\
\hline Completion & $2563(84.31 \%)$ & $2676(82.93 \%)$ & 3691 & 4012 \\
\hline Dropouts & 477 (16.69\%) & $551(17.07 \%)$ & Nil & Nil \\
\hline $\begin{array}{l}\text { Those that } \\
\text { returned Back to } \\
\text { School }\end{array}$ & Nil & Nil & $164(4.65 \%)$ & $340(9.26 \%)$ \\
\hline
\end{tabular}

Table 2 shows that completion rate before the feeding of pupils was less than the enrolment rate while all those that enrolled during the feeding programme completed primary education and those who dropped from school returned back to school.

An interpretation of this finding means that those who dropped from school before the feeding programme returned back to school. On the other hand, no pupil who enrolled during the feeding programme dropped from school. This is to say that feeding of pupils boost the enrolment, transition and completion rates but does not enhance drop out from school. The study established that before feeding of pupils, the completion rate stood at $82.93 \%-84.31 \%$ completion rates of for the period 1998/1999 - 2003/2004 and 1999/2000-2002/2005 sessions. This finding seem to confirm Obaji (2005) who found out that $17 \%$ of those who go to school do not complete primary school education. In support to Obaji's finding, Ogbuka (2000) reported that in 1996 the rate of completion of primary school education in Nigeria was 64.1\%. However, the Federal Republic of Nigeria (FRN) 2006 commissioned the Federal Ministry of Education/Universal Basic Education Commission to carry out what it described as national school census and found out that primary six completion rates were $69.2 \%$ in 2004 and $67.5 \%$ in 2005. The finding of Federal Ministry of Education/Universal Basic Education Commission shows a completion rate slightly lower than what this study established. The variation may be attributed to the fact that their study was a nationwide study while this, focused on Rivers State alone.

This study went further to establish that the academic period when feeding was introduced marked a significant increase in the pupils' completion rate. The period study also shows that a high number of pupils that dropped from school returned back to school. The study found out that within the feeding periods, 3527 enrolled but 3691 pupils completed their primary school education, and in another feeding period showed that out of 3672 that enrolled 4012 completed their primary school education. These periods were the academic sessions ending $2005 / 2006$ and 2006/2007. Therefore the periods ending 2005/2006 and 2006/2007 respectively witnessed 164 pupils return to school or $4.65 \%$ of pupils returned to school within the period 2005/2006 session when the feeding initially took off. Similarly in 2006/2007 session 340 pupils above the number of pupils who enrolled in primary one of the pupils graduating 2006/2007 returned back to school or $9.26 \%$ above the number of those who enrolled returned back to school. What this means is that those who dropped in previous years retuned back to school. Their return can be attributed to the feeding that was introduced. This was contrary to the years of no feeding in schools where those that dropped 
from school, did not return back to school. The preceding statement is made because the periods when there was no feeding, 3040 enrolled and 2563 completed in 2003/2004 and in 2004/2005 academic session 3227 enrolled and 2676. An analysis of the 2003/2004 and $2004 / 2005$ figures show that the enrollment rates were higher than the completion rates. This account simply shows that $15.70 \%$ of those who enrolled in $2003 / 2004$ dropped from school and in $2004 / 2005$ session $17,18 \%$ dropped. The testimony derivable from the analogy is that feeding of pupils is a viable strategy to enable all and sundry acquire the basic primary six school education.

Research question two: At what rate did urban and rural pupils complete primary education before and during the feeding programme?

Table three: Percentage analysis of completion rates of urban and rural pupils

\begin{tabular}{|c|c|c|c|c|c|c|c|c|}
\hline & \multicolumn{2}{|c|}{$\begin{array}{l}\text { Urban completion } \\
\text { rate before the feeding } \\
\text { programme }\end{array}$} & \multicolumn{2}{|c|}{$\begin{array}{l}\text { Urban completion } \\
\text { rate during the feeding } \\
\text { programme }\end{array}$} & \multicolumn{2}{|c|}{$\begin{array}{l}\text { Rural completion } \\
\text { rate before the feeding } \\
\text { programme }\end{array}$} & \multicolumn{2}{|c|}{$\begin{array}{l}\text { Rural completion } \\
\text { rate during the feeding } \\
\text { programme }\end{array}$} \\
\hline & $\begin{array}{c}1998 / 1999 \\
\text { to } \\
2003 / 2004\end{array}$ & $\begin{array}{l}1999 / 2000 \\
\text { to } \\
2005 / 2006\end{array}$ & $\begin{array}{l}2000 / 2001 \\
\text { to } \\
2005 / 2006\end{array}$ & $\begin{array}{l}2001 / 2002 \\
\text { to } \\
2006 / 2007\end{array}$ & $\begin{array}{l}1998 / 1999 \\
\text { to } \\
2003 / 2004\end{array}$ & $\begin{array}{l}1999 / 2000 \\
\text { to } \\
2004 / 2005\end{array}$ & $\begin{array}{l}2000 / 2001 \\
\text { to } \\
2005 / 2006\end{array}$ & $\begin{array}{l}2001 / 2002 \\
\quad \text { to } \\
2006 / 2007\end{array}$ \\
\hline Enrolment & 1795 & 1614 & 1859 & 1883 & 1458 & 1565 & 1712 & 1643 \\
\hline Completion & $\begin{array}{c}1673 \\
(93.20 \%)\end{array}$ & $\begin{array}{c}1473 \\
(91.26 \%)\end{array}$ & 1925 & 1910 & $\begin{array}{c}1373 \\
(94.17 \%) \\
\end{array}$ & $\begin{array}{c}1397 \\
(89.27 \%)\end{array}$ & 1781 & 1766 \\
\hline Dropouts & $\begin{array}{c}122 \\
(6.805 \%)\end{array}$ & $141(8.74 \%)$ & Nil & Nil & $85(5.83 \%)$ & $\begin{array}{c}168 \\
(10.71 \%)\end{array}$ & Nil & Nil \\
\hline $\begin{array}{l}\text { Those that } \\
\text { returned back } \\
\text { to school }\end{array}$ & Nil & Nil & $66(3.55 \%)$ & $27(1.43 \%)$ & Nil & Nil & $69(4.03 \%)$ & $\begin{array}{c}123 \\
(6.97 \%)\end{array}$ \\
\hline
\end{tabular}

Table 3 indicates that completion rate of urban and rural pupils are the same before and during the feeding programme and no significant difference was shown in terms of the dropout and return rates of the urban and rural pupils before and during the feeding programme.

Since there was no difference between the rates of completion, drop outs and return rates of pupils to school by urban and rural pupils in all respect, it means that the rural pupils who are considered to come more from poor homes did not utilize the feeding opportunity or the feeding programme was centered in the city. The axiom that the feeding programme may have been centered in the city may not be misleading because it is a common phenomenon with government projects and programmes in Nigeria. The government is known for centering its efforts in more populous places like the urban centers so as to attract praise from the people. The expression made so far can be attributed to the fact that the scheme would assist more children from less privileged than those of the privileged ones. Under every natural circumstances, the less privileged are likened to be found in the rural areas than the urban areas. In the light of this assumptions, one justifies the rationale why the then President of Nigeria, in the person of Goodluck Ebele Jonathan while flagging off the re-introduction of the pupils free feeding programme at Kano in 2011 noted that the scheme would lessen the burden on less privileged parents. Commenting on the usefulness of the scheme to the poor, carebune, Onyishi and Orjinkweke (2008) noted that, the main reason for the unpredictable rate of completion is the family economic factor. Besides, Onyishi and Orjinkweke's comment Aramide and Leif (2015) lamented that out of school children increase the illiteracy and poverty level of a country. It is important to reflect this, because it is worrisome that the children who dwell in the rural area and are deemed to be the major target of the feeding programme did not maximally utilize the opportunity. However, there is the need to note that feeding of pupils by government or agencies increases the rates of enrolment, transition and 
Anero, N. (2020). Comparison Of Pupils' Completion Rate Before And During 2006/2007 School Feeding Programme In Selected Public Primary Schools In Rivers State, Nigeria. Advances in Social Sciences Research Journal, 7(3) 195-202.

completion rates. In the same time decreases dropout rate or increase return rate of pupils to school.

Research Question 3: At what rate did male and female pupils complete primary education before and during the feeding programme?

Table four: Percentage analysis of completion rates of male and female pupils

\begin{tabular}{|c|c|c|c|c|c|c|c|c|}
\hline & \multicolumn{2}{|c|}{$\begin{array}{l}\text { Male completion } \\
\text { rate before the feeding } \\
\text { programme }\end{array}$} & \multicolumn{2}{|c|}{$\begin{array}{l}\text { Male completion } \\
\text { rate during the feeding } \\
\text { programme }\end{array}$} & \multicolumn{2}{|c|}{$\begin{array}{l}\text { Female completion } \\
\text { rate before the feeding } \\
\text { programme }\end{array}$} & \multicolumn{2}{|c|}{$\begin{array}{l}\text { Female completion } \\
\text { rate during the feeding } \\
\text { programme }\end{array}$} \\
\hline & $\begin{array}{l}1998 / 1999 \\
\text { to } \\
2003 / 2004\end{array}$ & $\begin{array}{c}1999 / 2000 \\
\text { to } \\
2005 / 2006\end{array}$ & $\begin{array}{l}2000 / 2001 \\
\text { to } \\
2005 / 2006\end{array}$ & $\begin{array}{l}2001 / 2002 \\
\text { to } \\
2006 / 2007\end{array}$ & $\begin{array}{l}1998 / 1999 \\
\text { to } \\
2003 / 2004\end{array}$ & $\begin{array}{c}1999 / 2000 \\
\text { to } \\
2004 / 2005\end{array}$ & $\begin{array}{l}2000 / 2001 \\
\text { to } \\
2005 / 2006\end{array}$ & $\begin{array}{l}2001 / 2002 \\
\text { to } \\
2006 / 2007\end{array}$ \\
\hline Enrolment & 1594 & 1672 & 1790 & 1921 & 1573 & 1697 & 1781 & 1817 \\
\hline Completion & $\begin{array}{c}1354 \\
(84.94 \%)\end{array}$ & $\begin{array}{c}1423 \\
(85.11 \%)\end{array}$ & 1882 & 2022 & $\begin{array}{c}1283 \\
(81.56 \%)\end{array}$ & $\begin{array}{c}1295 \\
(76.31 \%)\end{array}$ & 1924 & 1959 \\
\hline $\begin{array}{l}\text { Those that } \\
\text { returned back } \\
\text { to school }\end{array}$ & Nil & Nil & $92(5.14 \%)$ & $\begin{array}{c}101 \\
(4.10 \%)\end{array}$ & Nil & Nil & $\begin{array}{c}143 \\
(8.03 \%)\end{array}$ & $140(7.71 \%)$ \\
\hline
\end{tabular}

Table 4 shows that the completion rate of the boys and girls during the feeding programme was higher than the rate of completion before the feeding programme. The dropout rate of the female pupils was slightly higher than that of the male children and neither did the male nor female children dropout during the feeding programme, although an insignificant proportion of both the male and female children returned back to school during the feeding programme while none came back when there was no feeding.

Closely looking at the findings of this study, one can make bold to say that the percentage of completion of the boys and girls as at before and during the feeding programme is that, more of the male pupils who enroll in for primary education in Rivers State completed their courses than their female counterparts. This finding is unlike what is obtainable from other parts of the country. Usman (2006) explained that boys from Northern Nigeria do not enroll nor complete primary school education due to their engagement in cattle business. He further noted that the same situation is witnessed in Anambra State where boys abandon schools for trading and other economic activities. In support to this, Ossai and Oyibo (2008) noted that the decline in the number of boys that enroll and complete primary education, in Igbo-Eze local Government Area of Enugu state are in declining direction. He further explained that the young stars may pick up jobs such as commercial motor cycle riding which appears to be the most current business for the young stars. The higher rate of enrolment and completion of the boys in Rivers State when compared with those of Northern Nigeria and Anambra State may be attributed to the economic life style of the people in Rivers State. Rivers State is known for accommodating different industries and companies which may make it possible for school leavers to secure jobs. Besides, the jobs demand sound education; so they are bound to pursue it to its logical conclusion. The situation in Rivers State may not be applicable to the states in Northern Nigeria known for cattle rearing and Anambra known for trading and other forms of commercial activities.

\section{CONCLUSION}

It is not in dispute that feeding of pupils while at school is an effective measure that ensures good enrolment, transition and completion rates of primary education by the Nigerian child. The measures of feeding pupils is indeed a good measure. Unfortunately, the government abandoned the programme for reasons best known to them. In most countries it has been 
proven to be a catalyst to the drastic reduction of school drop-outs, improve quality and efficiency of the school system as well as promote basic education. From the findings of this study, the programme does not seem to cover all nook and cranny of the country since differences are not established in terms of the return rate of pupils from urban and rural areas of Rivers State, Considering the impact of the programme in areas where it was implemented, one can confidently say that government's magnanimity of feeding pupils is a welcomed development and has accounted for high achievement of completion rate of primary school education and drastic reduction in school dropouts among primary school pupils during the period of free feeding implementation programme in Rivers State.

\section{RECOMMENDATIONS}

Based on the findings of this study, the researcher recommends as follows:

1. Since feeding of pupils hold positive impact on the completion rate of primary education, the government of Rivers State need to re-introduce the school feeding programme as it is done in Kano and Lagos states of Nigeria.

2. The study established that rural pupils did not utilize the feeding programme, as they ought to, it will therefore be necessary to carry out an enlightenment campaign by all stakeholders through the mass media targeting at enlightening the rural dwellers about the dividends of the feeding programme.

3. On the other hand, the government needs to device ways of implementing the free feeding programme by seeking for participation of philanthropic in funding the programme in all the nooks and crannies of the state so that all and sundry shall benefit.

\section{References}

Aramide, K. and Leif J. (2015). School attendance and Nigerians: Understanding the impact of and interaction of gender, urban-rural residence and socioeconomic status. Ibadan: Macmillan

Betha, L. (2007). Primary prevention of child abuse. World Applied Science Journals 4(1), 36-44.

Breakly, J. (1997). The Role of diet and behaviour in childhood. Journal of Pediatrics and Child Health. 7(2), 101113.

Carebune, C. F., Onyishi, C. I. \& Orijinweke, O. G. (2008). Impact of students participating in family economic activities and their selected educational output variables. An unpublished first degree project. Department of Guidance and Counselling, University of Nigeria Nsukka.

Federal Republic of Nigeria (2006). School census report. Abuja: Federal Ministry of Education.

Gaduya, N. C. (2018). Learners' variables and pupils' enrollment, transition and completion rates in public primary schools in Rivers West Senatorial District of Rivers State. An M.Ed degree thesis submitted in partial fulfillment of the award of Master of Education. Department of Early Childhood and Primary Education, Faculty of Education, Ignatius Ajuru University of Education, Port Harcourt.

Jagagba, M. M. (2008). Implementation of the UBE programme in Nigeria: The role of the Federal Government. Journal of Childhood and Primary Education. 4(1), 67-68.

Obaji, C. N. (2005). Nigeria's experience with girls education and linkages with action on adult female literacy to impact on poverty alleviation. Statement by Nigeria's Honorable Minister of Education at the United Nations girls education initiative consultative meeting held at Beijing China on $26^{\text {th }}$ November.

Obanya, P. (2001). Major management challenges of UBE. A Journal of Basic Education in Nigeria. 1(1), 13-22.

Ogbuka, C. (2000). Gearing up for the Universal Basic Education. Retrieved from http://wwwpunchontheweb.com on $18^{\text {th }}$ December, 2010.

Ossai, L. E. \& Oyibo, F. G. (2008). Factors that a responsible for low enrolment of boys in post-primary schools in Enugu State: A case study of Igb-Eze South Local Government Area. An unpublished first degree project. Department of Educational Planning and Administration, University of Nigeria Nsukka.

Otive, I. (2006). Financing quality basic education in nigeria. A keynote address delivered at a round table organized by the Common Wealth Education at Abuja, $5^{\text {th }}$ September, organized by Action Aid International Nigeria. 
Anero, N. (2020). Comparison Of Pupils' Completion Rate Before And During 2006/2007 School Feeding Programme In Selected Public Primary Schools In Rivers State, Nigeria. Advances in Social Sciences Research Journal, 7(3) 195-202.

Rivers State Universal Education Board (2012). Statistical data of staff and local government eduation authorities and pupils enrolment. Port Harcourt: Minson Publishers.

Usman, L. (2006). Rural nomadic fulbe boys primary schooling: Assessing repertoires of practice in Nigeria. McGill Journal of Education, 41 (2), 155-173. 